\title{
Editorials
}

\section{The McCoy laryngoscope in infants and children}

Éamon McCoy MD FFARCSI

$\longrightarrow$

ECHNIQUES of intubating the trachea in infants and children differ from adults due to important differences in anatomy. These differences are more pronounced in the neonate. ${ }^{1}$ To align the axes of the mouth, oropharynx and trachea in a child over six years old, the head should be extended at the atlanto-occipital joint while being elevated $5-10 \mathrm{~cm}$ on a pillow. ${ }^{2}$ In infants and younger children head extension at the atlanto-occipital joint alone will align the airway axes as the head is proportionately larger compared to the trunk. In addition there are anatomical differences in the airway itself which are relevant. The infant trachea has an anterior inclination, the larynx is situated at a higher level relative to the vertebrae, the epiglottis is narrow, short, $\mathrm{U}$ shaped and extends into the pharynx, the tongue is much larger in relation to the oral cavity and the angle of the mandible is greater. ${ }^{3}$ As the distances between the tongue, hyoid bone, epiglottis and the roof of the mouth are shorter, the tongue is closer to both the soft palate and the superior larynx. This results in a more acute angulation between the plane of the tongue and the plane of the glottic opening.

Despite the fact that Macintosh condemned them as anatomically wrong and unnecessary, most blades designed for laryngoscopy in infants and children tend to be either straight or with a shallow curve at the tip only. ${ }^{4}$ As a result of the anatomical differences, straight blade laryngoscopes may more completely elevate the tongue, removing it from the field of view and facilitate better visualization of the infant larynx. These are designed to be inserted deeper into the pharynx as well as posterior to the epiglottis. However this is not necessarily standard practice, with some laryngoscopists preferring to place the tip of a straight blade into the vallecula and others preferring a curved blade even in infants. ${ }^{3,5} \mathrm{~A}$ large variety of blades are currently available and the choice of a particular blade is largely a matter of preference.
Since the advent of tracheal intubation in anesthesia, descriptions of at least 50 laryngoscope blade designs have been published, and many more exist unpublished. ${ }^{6}$ Commonly used pediatric straight blades include the Anderson-Magill, Robertshaw, Seward, Wis-Hipple, Flagg and Miller. The McCoy laryngoscope was developed in the early 1990's as an aid to difficult intubation in adult patients. ${ }^{7}$ It has been evaluated in situations of both standard and difficult laryngoscopy, in patients with limited neck extension, in simulated cervical spine injuries and after application of a cervical collar. ${ }^{8-14}$ It has also been shown to reduce the stress response to laryngoscopy, probably as a result of the reduction in required force. ${ }^{15-17}$ However it has also been noted that it will not always improve laryngoscopic view and on occasion may indeed worsen the view, probably due its more complex construction and its biomechanics. ${ }^{9,18,19}$ More recently, a pediatric version of the McCoy laryngoscopy has become available, based on the Seward straight blade. This blade has not been investigated in pediatric practice.

In this issue of the journal Iohom et al. report on a comparison of the McCoy and the Miller straight laryngoscope blades in children under six months of age with regard to the best view obtained and the times to best laryngoscopic view and intubation. ${ }^{20}$ Under the conditions of this study these data appear to show that the McCoy laryngoscope does not confer an advantage over the Miller blade. However this study should be discussed in the context of the problems associated with any evaluation of different laryngoscope designs.

The first problem is that in assessing a new instrument it is essential that the instrument is used correctly in order to take advantage of its design. In infants and young children several techniques of laryngoscopy are employed to elevate the epiglottis. One technique

From the Department of Clinical Anaesthesia, The Royal Victoria Hospital, Belfast, Northern Ireland.

Address correspondence to: Dr. Éamon McCoy, Department of Clinical Anaesthesia, The Royal Victoria Hospital, Grosvenor Road, Belfast BT12 6 BA, Northern Ireland. Phone: 028-90240503, ext. 4006/2717; Fax: 028-90325725; E-mail: eamonmccoy@ireland.com 
consists of advancing the blade into the esophagus and then withdrawing it until the glottis comes into view. However this may result in laryngeal trauma as the blade tip scrapes the arytenoids and aryepiglottic folds. ${ }^{3}$ Another consists of advancing the tip under direct vision until the epiglottis is seen, placing the tip posterior to the epiglottis and then elevating it directly. As the posterior surface of the epiglottis is in direct contact with the laryngoscope tip, both of these techniques may result in reflex stimulation and trauma to both the epiglottis and the glottis. A third method is to place the tip of either a straight or curved blade into the vallecula as in adult laryngoscopy. This will lift the hyo-epiglottic ligament, elevate the epiglottis and expose the larynx. However, in infants this technique may require greater angulation of the whole blade or external laryngeal manipulation in order to achieve an adequate view compared to when the epiglottis is lifted directly. ${ }^{5}$ The McCoy pediatric blade has been designed to confer the advantages of the straight blade in aligning the various axes in the infant airway while allowing the epiglottis to be lifted with the tip in the vallecula. This should allow a view comparable to that of a straight blade and this has been our clinical experience. As the tip is not in contact with the posterior surface of the epiglottis this should reduce the reflex stimulation and trauma to both the epiglottis and glottis. Iohom and colleagues placed the tip of the McCoy laryngoscope blade posterior to the epiglottis thus not taking advantage of its unique design and using it almost as a straight blade. This is likely to have affected the results obtained and invalidate comparison. Perhaps it would have been interesting to have a group where the McCoy blade was used in the way it was intended to be used.

Standardization of the intubating technique is another problem in conducting research on laryngoscopy. Since standardization is the norm in all other areas of medical research, it should also be applied to airway research and many previous clinical studies of laryngoscopy have suffered from poor design due to lack of standardization..$^{21}$ Elements of this should include the use of a standardized intubating position and controlled positioning of the larynx. ${ }^{22,23}$ Whether or not these were used in Iohom's study is not reported.

A shortcoming of the Iohom's study may be evaluation during anesthesia without the use of muscle relaxants, based on the study of Politis et al. ${ }^{24} \mathrm{~A}$ technique that does not employ a muscle relaxant and neuromuscular monitoring will always raise the possibility that laryngoscopy in different patients, or even in the same patient at different times, might have been conducted at differing levels of muscular relaxation.
Politis and colleagues found that to successfully intubate $80 \%$ of children using $8 \%$ sevoflurane and no muscle relaxant, induction times of 137 and $187 \mathrm{sec}$ were required in children of one to four years and four to eight years respectively. ${ }^{24}$ They reported inadequate intubating conditions in 24 of 153 patients. As Politis et al. were not able to extrapolate clinically meaningful confidence intervals at points away from where data were collected, there is no guarantee that conditions for laryngoscopy would be any better in infants after $240 \mathrm{sec}$ of $8 \%$ sevoflurane, which is when laryngoscopy was conducted by Iohom. In addition, after laryngoscopy with the first instrument, Iohom allowed only a further one minute of sevoflurane inhalational anesthesia before laryngoscopy was attempted with the second instrument. The level of muscle relaxation or even the depth of anesthesia itself may therefore have been inadequate and certainly variable. Inadequacy of this technique in this study is further demonstrated by the desaturation reported in both groups after intubation. Though the use of sevoflurane alone without relaxant is certainly appropriate in clinical practice, standardization demands that anesthesia for comparisons in laryngoscopy should have included the use of muscle relaxants and confirmation of complete neuromuscular block in all subjects before laryngoscopy is attempted, or at least demonstration of adequate depth of anesthesia.

Assessment of the view obtained at laryngoscopy is both difficult and subjective. Using only a single observer in the assessment of view makes this even more so. However in laryngoscopy research an accurate record of view is essential and laryngeal imaging may provide objectivity in this type of research. ${ }^{19,21,23}$ Though it has been claimed that the very act of photographing the laryngeal view may itself interfere with the laryngoscopy, unobtrusive and rapid methods of recording the view obtained have been described. ${ }^{19,21,25}$ The results of the study such as the one reported by Iohom et al. would be more objective by the use of such a technique.

It appears that the authors encountered what appears to be an unusually high incidence of Cormac and Lehane grade 2 and 3 views at laryngoscopy. Even with a Miller blade in a population of 40 patients with no obvious abnormalities of the head or neck it must be unusual to encounter 11 patients $(25 \%)$ with other than a grade 1 view at laryngoscopy. Factors that may account for this may be inappropriate patient selection, the inadequacy of the Cormac and Lehane grading system in pediatric laryngoscopy, an anesthetic technique that did not include a muscle relaxant, suboptimal patient positioning or laryngoscopy being 
performed by personnel relatively inexperienced in the use of the McCoy blade, particularly in children.

Clinical practice is not rigidly standardized, but clinical research must be standardized, particularly in areas such as laryngoscopy with multiple influential components, if valid conclusions are to be made. ${ }^{21}$ As a result of these problems, if differences exist between the Miller and McCoy laryngoscope blade in infants, it may need more standardized studies for demonstration. However, in spite of the limitations in the Iohom study, it is possible that the McCoy blade might reasonably not be expected to improve an easy view of the larynx.

\section{L'usage du laryngo- scope McCoy chez les enfants}

Les techniques d'intubation trachéale ne sont pas les mêmes chez les enfants et les adultes en raison d'importantes différences anatomiques. Ces différences sont plus prononcées chez le nouveau-né. ${ }^{1}$ Pour aligner les axes de la bouche, de l'oropharynx et de la trachée chez un enfant de plus de six ans, il faut une extension de la tête à l'articulation atlanto-occipitale en même temps qu'une élévation de $5-10 \mathrm{~cm}$ sur un oreiller. ${ }^{2}$ Chez les jeunes enfants, l'extension de la tête à l'articulation atlanto-occipitale permet parfois à elle seule d'aligner les axes des voies aériennes, car la tête est proportionnellement plus large que le tronc. En outre, certaines différences anatomiques des voies aériennes sont elles-mêmes significatives. La trachée de l'enfant présente une inclinaison antérieure, le larynx est situé plus haut par rapport aux vertèbres, l'épiglotte est étroite, courte, en forme de U et s'étend dans le pharynx, la langue est plus grosse, en relation avec la cavité orale, et l'angle mandibulaire est plus grand. ${ }^{3}$ Comme les distances entre la langue, l'os hyoïde, l'épiglotte et la voûte du palais sont plus courtes, la langue est à la fois plus près du palais mou et du larynx supérieur. Cette situation crée une angulation plus aiguë entre le plan de la langue et le plan de l'ouverture glottique.

Malgré que Macintosh les ait jugées anatomiquement inadaptées et non nécessaires, la plupart des lames conçues pour la laryngoscopie chez les enfants sont plutôt droites ou légèrement courbes à la pointe seulement. ${ }^{4}$ Étant donné les différences anatomiques, les laryngoscopes à lame droite peuvent élever la langue plus complètement, la retirant du champ de vision, et faciliter une meilleure visualisation du larynx. Ces lames sont conçues pour s'insérer plus profondément dans le pharynx et postérieurement à l'épiglotte. Mais ce n'est pas une pratique nécessairement régulière, certains examinateurs préférant placer la pointe de la lame droite dans la vallécule et d'autres préférant une lame courbe même chez les nouveaunés. ${ }^{3,5}$ Une grande variété de lames sont actuellement sur le marché et le choix d'une lame particulière demeure surtout une question de préférence.

Depuis l'avènement de l'intubation trachéale en anesthésie, les descriptions d'au moins 50 lames de laryngoscopes différentes ont été publiées et de nombreuses autres existent, non publiées. ${ }^{6}$ Les lames droites souvent utilisées en pédiatrie comprennent les lames Anderson-Magill, Robertshaw, Seward, WisHipple, Flagg et Miller. Le laryngoscope McCoy a été mis au point au début des années 1990 pour faciliter l'intubation difficile chez les patients adultes. ${ }^{7}$ Il a été évalué dans des cas de laryngoscopie normale et difficile, d'extension limitée du cou, de lésions simulées de la colonne cervicale et d'application d'un collet cervical. ${ }^{8-14}$ On a démontré aussi qu'il réduit la réaction de stress à la laryngoscopie, probablement en réponse à la réduction de la force nécessaire à la manoeuvre. ${ }^{15-17}$ Cependant, on a également constaté qu'il n'améliore pas toujours la vision laryngoscopique et qu'il peut à l'occasion l'altérer, sans doute à cause de la complexité de sa conception et de sa biomécanique..$^{9,18,19}$ Plus récemment, une version pédiatrique du laryngoscope McCoy a été produite à partir d'une lame droite Seward. Cette lame n'a pas encore été expérimentée en pédiatrie.

Dans le présent numéro du journal, Iohom et coll. présentent une comparaison des lames droites des laryngoscopes McCoy et Miller, utilisées chez des enfants de moins de six mois, en regard de la meilleure vue obtenue et des meilleurs temps pour obtenir cette vue laryngoscopique qui permet l'intubation..$^{20}$ Dans les conditions de l'étude, ces données montrent que le laryngoscope McCoy n'est pas plus avantageux que la lame Miller. Il faudrait cependant examiner l'étude dans le contexte des problèmes associés à toute évaluation des différents modèles de laryngoscopes.

Le premier de ces problèmes est qu'en évaluant un nouvel instrument, il est essentiel de l'utiliser correctement pour tirer avantage de sa conception. Chez les enfants, certaines techniques de laryngoscopie visent à élever l'épiglotte. L'une d'elles consiste à avancer la lame dans l'œsophage et à la retirer ensuite 
jusqu'à ce que la glotte soit visible. Toutefois, cela peut causer un traumatisme laryngé, si la pointe de la lame érafle les plis aryténoïdes et aryépiglottiques. ${ }^{3}$ Une autre façon de procéder consiste à avancer la pointe sous laryngoscopie directe jusqu'à voir l'épiglotte, en plaçant la pointe derrière l'épiglotte et en la soulevant ensuite directement. La surface postérieure de l'épiglotte étant en contact direct avec la pointe du laryngoscope, ces deux techniques peuvent provoquer une stimulation réflexe et un traumatisme de l'épiglotte et de la glotte. Une troisième méthode consiste à placer la pointe de la lame, droite ou courbe, dans la vallécule comme pour la laryngoscopie adulte. On soulève ainsi le ligament hyoépiglottique, élève l'épiglotte et expose le larynx. Chez les enfants, la technique peut toutefois exiger une plus grande angulation de toute la lame ou une manipulation externe du larynx pour obtenir une vue adéquate comparée à celle qu'on obtient quand l'épiglotte est soulevée directement. ${ }^{5}$ La lame pédiatrique McCoy a été fabriquée pour conférer les avantages de la lame droite en alignant les divers axes dans les voies aériennes de l'enfant tout en permettant de soulever l'épiglotte avec la pointe dans la vallécule. La technique devrait permettre une vue comparable à celle d'une lame droite comme nous l'avons expérimenté dans notre clinique. La pointe n'étant pas en contact avec la surface postérieure de l'épiglotte, cela devrait réduire la stimulation réflexe et le traumatisme à la fois de l'épiglotte et de la glotte. Iohom et ses collègues ont placé la pointe de la lame McCoy derrière l'épiglotte. Ce faisant, ils n'ont donc pas tirer avantage de sa conception unique et l'ont utilisée presque comme une lame droite. Ce qui a sans doute influencé les résultats obtenus et invalidé la comparaison. Il aurait pu être intéressant d'utiliser, chez un groupe de patients, la lame McCoy selon sa conception première.

La normalisation de la technique d'intubation est un autre problème de ce genre de recherche en laryngoscopie. La normalisation s'applique à tous les autres domaines de la recherche médicale et devrait faire partie aussi de la recherche sur les voies aériennes. De nombreuses études cliniques antérieures ont souffert d'un devis de recherche inadapté, justement à cause d'une absence de normalisation. ${ }^{21}$ Les éléments à inclure doivent comprendre l'usage d'une position d'intubation normalisée et d'une mise en place contrôlée du larynx. ${ }^{22,23}$ L'étude de Iohom ne dit pas s'ils ont été utilisés ou non.

Un défaut de l'étude de Iohom pourrait être l'évaluation pendant l'anesthésie sans myorelaxants, fondée sur l'étude de Politis et coll. ${ }^{24}$ Une technique qui n'emploie pas de monitorage du myorelaxant et de la composante neuromusculaire soulève toujours la possibilité que la laryngoscopie chez différents patients, ou chez un même patient à différents moments, ait été réalisée sous différents niveaux de relâchement musculaire. Politis et ses collaborateurs ont trouvé que pour réussir l'intubation chez $80 \%$ des enfants en utilisant du sévoflurane à $8 \%$ et aucun myorelaxant, des temps d'induction de 137 et $187 \mathrm{sec}$ étaient nécessaires chez des enfants de un à quatre ans et de quatre à huit ans, respectivement. ${ }^{24} \mathrm{Ils}$ ont constaté des conditions inadéquates d'intubation chez 24 des 153 patients. Comme Politis et coll. n'ont pu extrapoler d'intervalles de confiance significatifs des points à partir desquels les données avaient été recueillies, rien ne garantit que ces conditions de laryngoscopie auraient été meilleures après $240 \mathrm{sec}$ de sévoflurane à $8 \%$, moment où la laryngoscopie a été pratiquée par Iohom. De plus, après la laryngoscopie avec le premier instrument, Iohom n'a accordé qu'une minute de plus à l'anesthésie par inhalation de sévoflurane avant d'utiliser le deuxième instrument. Le niveau de relâchement musculaire ou même la profondeur de l'anesthésie ellemême ont pu alors être inadéquats et certainement variables. Les déficiences de cette technique sont aussi démontrées dans l'étude par la désaturation rapportée dans les deux groupes après l'intubation. L'usage de sévoflurane seul, sans myorelaxant, est certainement approprié en pratique clinique, mais la normalisation demande que l'anesthésie réalisée dans le but de comparer des examens laryngoscopiques inclut l'emploi de myorelaxants et la confirmation d'un blocage neuromusculaire complet, ou au moins la démonstration d'une profondeur d'anesthésie suffisante, chez tous les sujets avant que la laryngoscopie ne soit tentée.

L'évaluation de la vue obtenue à la laryngoscopie a été tout à la fois difficile et subjective. Le fait de n'avoir qu'un seul observateur vient renforcer cette idée. Cependant, en recherche laryngoscopique, un bilan exact de la vision est essentiel et l'imagerie du larynx peut fournir l'objectivité dans ce type de recherche. ${ }^{19,21,23}$ Malgré le fait qu'on ait déclaré que l'acte même de photographier la vue du larynx pouvait gêner la laryngoscopie, des méthodes non obstructives et rapides d'enregistrer la vue obtenue ont été décrites. ${ }^{19,21,25}$ Les résultats de l'étude, comme celle qui est rapportée par Iohom et coll., auraient pu être plus objectifs avec l'usage d'une technique semblable.

Il semble que les auteurs ont fait face à une incidence élevée inhabituelle de grade 2 et 3 de Cormac et Lehane à la laryngoscopie. Même avec une lame Miller chez une population de 40 patients sans anomalies apparentes de la tête ou du cou, il est rare de voir 11 patients $(25 \%)$ avec autre chose qu'un grade 1 de 
visibilité à la laryngoscopie. Les facteurs en cause peuvent être une sélection de patients inappropriée, un système de cotation de Cormac et Lehane mal adapté à la laryngoscopie pédiatrique, une technique anesthésique sans myorelaxant, la position sous-optimale du patient ou la réalisation de la laryngoscopie par du personnel relativement inexpérimenté dans l'usage de la lame McCoy, surtout chez les enfants.

La pratique clinique n'est pas strictement normalisée, mais la recherche clinique doit être normalisée si on doit tirer des conclusions valides ${ }^{21}$, particulièrement dans des domaines comme la laryngoscopie avec de multiples composantes influentes. Comme conséquences de ces problèmes, si des différences existent entre l'usage des lames Miller et McCoy chez les enfants, nous pourrions avoir besoin de plus d'études normalisées pour en faire la démonstration. Mais, en dépit des limites de l'étude de Iohom, il est possible que la lame McCoy ne puisse raisonnablement améliorer une visualisation facile du larynx.

\section{References}

1 Ellis H, Feldman S. Anatomy for Anaesthetists. Oxford: Blackwell Scientific Publications; 1983.

2 Shorten GD, Armstrong DC, Roy WI, Brown L. Assessment of the effect of head and neck position on upper airway anatomy in sedated paediatric patients using magnetic resonance imaging. Paediatr Anaesth $1995 ; 5: 243-8$.

3 Wheeler M, Cote CJ, Todres D. Pediatric airway. In: Cote CJ, Todres D, Ryan JF, Goudsouzian NG (Eds.). A Practice of Anesthesia for Infants and Children, $3 \mathrm{ed}$. Philadelphia: WB Saunders Company; 2001.

4 Moyle JTB, Davey A. Airway management devices. In: Ward C (Ed.). Ward's Anaesthesic Equipment, 4th ed. London: WB Saunders Company; 1998.

5 Dunne NM. Paediatric intubation. In: Latto IP, Vaughan RS (Eds.). Difficulties in Tracheal Intubation. London: WB Saunders Company; 1997.

6 Marks RRD, Hancock R, Charters P. An analysis of laryngoscope blade shape and design: new criteria for laryngoscope evaluation. Can J Anaesth 1993; 40: 262-70.

7 McCoy EP, Mirakhur RK. The levering laryngoscope. Anaesthesia 1993; 48: 516-9.

8 Tuckey JP, Cook TM, Render CA. An evaluation of the levering laryngoscope. Anaesthesia 1996; 51: 71-3.

9 Cook TM, Tuckey JP. A comparison between the Macintosh and the McCoy laryngoscope blades. Anaesthesia 1996; 51: 977-80.

10 Chisholm DG, Calder I. Experience with the McCoy laryngoscope in difficult laryngoscopy. Anaesthesia 1997; 52: 906-8.

11 Aoyama K, Nagaoka E, Takenaka I, Kadoya T. The
McCoy laryngoscope expands the laryngeal aperture in patients with difficult intubation (Letter).

Anesthesiology 2000; 92: 1855-6.

12 Uchida T, Hikawa $\Upsilon$, Saito $\Upsilon$, Yasuda K. The McCoy levering laryngoscope in patients with limited neck extension. Can J Anaesth 1997; 44: 674-6.

13 Laurent SC, de Melo AE, Alexander-Williams JM. The use of the McCoy laryngoscope in patients with simulated cervical spine injuries. Anaesthesia 1996; 51: $74-5$.

14 Gabbott DA. Laryngoscopy using the McCoy laryngoscope after application of a cervical collar. Anaesthesia 1996; 51: 812-4.

15 McCoy EP, Mirakhur RK, McCloskey BV. A comparison of the stress response to laryngoscopy. The Macintosh versus the McCoy blade. Anaesthesia 1995; 50: 943-6.

16 Nishiyama T, Higashizawa T, Bito H, Konishi A, Sakai $T$. Which laryngoscope is the most stressful in laryngoscopy; Macintosh, Miller or McCoy? (Japanese). Masui 1997; 46: 1519-24.

17 McCoy EP, Mirakhur RK, Rafferty C, Bunting H, Austin BA. A comparison of the forces exerted during laryngoscopy. The Macintosh versus the McCoy blade. Anaesthesia 1996; 51: 912-5.

18 Prichard C. Comparison of the Macintosh and McCoy laryngoscope blades (Letter). Anaesthesia 1997; 52: 185-6.

19 Levitan RM, Ochroch EA. Explaining the variable effect on laryngeal view obtained with the McCoy laryngoscope (Letter). Anaesthesia 1999; 54: 599-601.

20 Iohom G, Franklin R, Casey W, Lyons B. The McCoy straight blade does not improve laryngoscopy and intubation in normal infants. Can J Anesth 2004; 51: 155-9.

21 Groom P, Hawkins M. Comparison of the Macintosh and McCoy laryngoscope blades (Letter). Anaesthesia 1997; 52: 802.

22 Horton WA, Fahy L, Charters P. Defining a standard intubating position using "angle finder". Br J Anaesth 1989; 62: 6-12.

23 Hawkins M, Groom P. Comparison of the Macintosh and McCoy laryngoscope blades (Letter). Anaesthesia 1997; 52: 276.

24 Politis GD, Frankland MJ, James RL, ReVille JF, Rieker $M P$, Petree BC. Factors associated with successful tracheal intubation of children with sevoflurane and no muscle relaxant. Anesth Analg 2002; 95: 615-20.

25 Hawkins M, Groom P. Comparison of the Macintosh and McCoy laryngoscopy blades. Anaesthesia 1997; 52: 280-1. 